\title{
鉄筋コンクリート橋脚・主鉄筋段落し部の 耐震判定法とその適用
}

\author{
川島一彦 ${ }^{1} \cdot$ 星隈順一 $^{2} \cdot$ 運上茂樹 $^{3}$ \\ ${ }^{1}$ フェロー会員 工博 東京工業大学工学部土木工学科教授 (テ152 東京都目黒区大岡山2-12-1) \\ 正会員工修 建設省土木研究所耐震研究室研究員 (テ305 茨城県つくば市大字旭 1 番地) \\ ${ }^{3}$ 正会員 工博 建設省土木研究所耐震研究室主任研究員
}

\begin{abstract}
既設鉄筋コンクリート橋脚の主鉄筋段落し部における耐震性を適切に評価するために，主鉄筋の段落し 位置を変化させた模型供試体の正負交番載荷実験を行い, 段落しを有する鉄筋コンクリート橋脚の破壊特 性等について検討した．実験結果を基に, 段落し部での損傷の可能性と, 設計地震力を超える地震力が作 用した場合に段落し部に生じる損傷度を，新たに定義した損傷形態判別係数と降伏曲げに対する安全率で 評価する簡便な耐震判定法を提案した，さらに，本判定法を適用すれば，段落し部で耐震性に劣る鉄筋コ ンクリート橋脚を精度よく抽出できることを, 最近の地震による被害橋脚の解析結果から明らかにした.
\end{abstract}

Key Words : reinforced concrete bridge piers, terminated reinforcement, seismic evaluation, cyclic loading test, damage analysis

\section{1. まえがき}

近年の地震による道路橋の被害の中で重要な点の 1つは，鉄筋コンクリート橋脚の主鉄筋段落し部に おいて多数の損傷が生じていることである.この種 の被害としては, 昭和 57 年の浦河沖地震による静内 橋の被害 ${ }^{11}$ が代表的であり, 平成5年1月の釧路沖地 震, 7月の北海道南西沖地震でも同様な被害が生じ

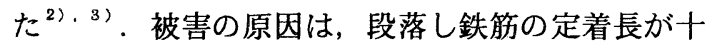
分でなかったためである ${ }^{4)}$ ５．段落し部での損傷 は，曲げによる損傷からぜい性的なせん断破壊に移 行しやすく, 近年の地震被害形態の中では, 落橋と いう致命的な被害に最も至りやすいと考えられてい る. したがって，既設の鉄筋コンクリート橋脚に対 しては，主鉄筋の段落し部に注意して耐震性を照査 しておくことが, 震前対策上重要である.

段落し鉄筋の定着長に関しては, 従来重ね継手長 の規定をそのまま準用していたが, 昭和55年の道路 橋示方書IV 下部構造編において, 段落しされない連 続した主鉄笳の引張応力が許容応力の $1 / 2$ 以下にな る断面まで定着するように規定が改訂された。 さら に, 定着部のコンクリートの許容せん断応力度が一 般部の $2 / 3$ に低減された ${ }^{6)}$ 。このため, 昭和 55 年道
路橋示方書以後の設計基準に準拠して設計された鉄 筋コンクリート橋脚では，段落し部の耐震性につい ては問題は少ないが，それ以前の設計基準で設計さ れた鉄筋コンクリート橋脚に対しては, 現在の耐震 設計レベルから見ると, 段落し部での耐震性が相対 的に低いものがある.このような鉄筋コンクリート 橋脚に対しては, その耐震性を適切に評価し, 必要 に応じて耐震補強を施していく必要があり, そのた めには，耐震点検等の実務の中でも取り扱いやすい 簡便な耐震判定法の開発が望まれている.

主鉄筋段落しがじん性率やせん断耐力に及ぼす影 響等に関しては, 石橋ら ${ }^{72}$, 山本ら ${ }^{8)}$, 尾坂 ${ }^{9), 10) ~}$ によって詳細に検討されている.こうした研究によ り, 段落し部の主鉄筋に生じるひずみや破壊のメカ ニズム，さらには段落し部の設計法に関して貴重な 知見が得られている. しかし，上述したように既存 の橋脚の耐震性判定に用いることができるような段 落し部の照查法としてはまとめられておらず，こう した研究は現在までにほとんど行われていないのが 現状である.

本研究では，まず主鉄筋段落し部の耐震安全性を 明らかにするために，主鉄筋の段落し高さをパラメ 一夕とした模型供試体による正負交番載荷実験を行 
Table 1 Test Specimens

\begin{tabular}{|c|c|c|c|c|c|c|c|c|c|c|c|c|c|}
\hline \multirow{3}{*}{$\begin{array}{l}\text { Speci- } \\
\text { men }\end{array}$} & \multirow{3}{*}{$\begin{array}{l}\text { Dimension } \\
\text { of the } \\
\text { Cross } \\
\text { Section } \\
\text { (cm) }\end{array}$} & \multirow{3}{*}{$\begin{array}{c}\text { Effective } \\
\text { Height } \\
\text { (cm) }\end{array}$} & \multirow{3}{*}{$\begin{array}{l}\text { Shear } \\
\text { Span } \\
\text { Ratio }\end{array}$} & \multicolumn{5}{|c|}{ Main Reinforcement } & \multicolumn{3}{|c|}{ Hoop Reinforcement } & \multirow{3}{*}{$\begin{array}{l}\text { Strength } \\
\text { of } \\
\text { Concrete } \\
\text { (MPa) }\end{array}$} & \multirow{3}{*}{$\begin{array}{l}\text { Axial } \\
\text { Stress } \\
\text { (MPa) }\end{array}$} \\
\hline & & & & \multirow{2}{*}{ Material } & \multirow{2}{*}{$\begin{array}{l}\text { Yielding } \\
\text { Stress } \\
\text { (MPa) }\end{array}$} & \multirow{2}{*}{$\begin{array}{l}\text { Termination } \\
\text { Height from } \\
\text { Base } \mathrm{h}_{c}(\mathrm{~cm})\end{array}$} & \multicolumn{2}{|c|}{ Reinforcement Ratio pl (\%) } & \multirow{2}{*}{ Material } & \multirow{2}{*}{$\begin{array}{l}\text { Yielding } \\
\text { Stress } \\
\text { (MPa) }\end{array}$} & \multirow{2}{*}{$\begin{array}{l}\text { Hoop Re- } \\
\text { inforcement } \\
\text { Ratio pw (\%) }\end{array}$} & & \\
\hline & & & & & & & Base & Termination & & & & & \\
\hline$P-10$ & \multirow{7}{*}{$\begin{array}{l}50 \text { X } 50 \\
\text { (Square) }\end{array}$} & \multirow{4}{*}{250} & \multirow{4}{*}{5.4} & \multirow{8}{*}{$\begin{array}{c}\text { SD295 } \\
\text { D13 }\end{array}$} & \multirow{5}{*}{308} & - & \multirow{7}{*}{2.03} & \multirow{7}{*}{1.01} & \multirow{8}{*}{$\begin{array}{c}\text { SR235 } \\
\phi 9\end{array}$} & \multirow{4}{*}{272} & \multirow{7}{*}{0.10} & 31.3 & \\
\hline $\mathrm{P}-14$ & & & & & & 110 & & & & & & 32.1 & \\
\hline $\mathrm{P}-15$ & & & & & & 135 & & & & & & 32.6 & 0 \\
\hline$P-16$ & & & & & & 160 & & & & & & 31.9 & \\
\hline $\mathrm{R}-1$ & & \multirow{3}{*}{460} & \multirow{3}{*}{9.9} & & & 180 & & & & \multirow{3}{*}{285} & & 42.1 & \multirow{3}{*}{1.0} \\
\hline $\mathrm{R}-2$ & & & & & \multirow[t]{2}{*}{346} & 205 & & & & & & 40.1 & \\
\hline $\mathrm{R}-3$ & & & & & & 230 & & & & & & 38.2 & \\
\hline $\mathrm{R}-4$ & $\begin{array}{l}60 / \$ 41.6^{*} \\
\text { (Hollow) }\end{array}$ & \multirow{6}{*}{260} & 4.9 & & 364 & 103 & 4.43 & 1.73 & & 336 & 0.28 & 35.4 & 2.1 \\
\hline $\mathrm{R}-8$ & \multirow{4}{*}{$\begin{array}{l}50 \times 50 \\
\text { (Square) }\end{array}$} & & \multirow{4}{*}{5.6} & \multirow{5}{*}{$\begin{array}{c}\text { SD295 } \\
\text { D10 }\end{array}$} & 357 & & & & & 245 & & 28.5 & \\
\hline $\mathrm{R}-12$ & & & & & & 90 & 1.31 & 0.63 & & & & 42.1 & 1.1 \\
\hline $\mathrm{R}-13$ & & & & & 409 & & & & SR235 & 434 & & 43.7 & 2.3 \\
\hline $\mathrm{R}-14$ & & & & & & 100 & 0.86 & 0.40 & & & 0.05 & 37.4 & 1.1 \\
\hline $\mathrm{R}-15$ & $\begin{array}{r}40 \times 160 \\
\text { (Wall type) }\end{array}$ & & 7.1 & & 367 & 80 & 0.76 & 0.40 & & 357 & & 35.3 & 1.0 \\
\hline
\end{tabular}

*) External / Internal diameters

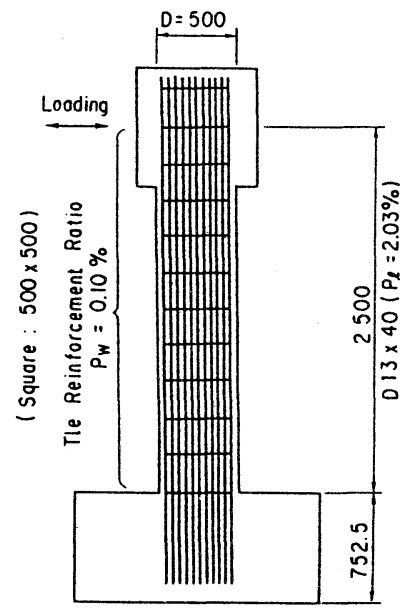

(a) Specimen $\mathrm{P}-10$

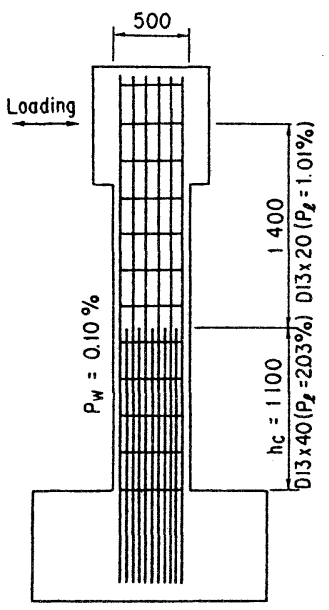

(b) Specimen $\mathrm{P}-14$

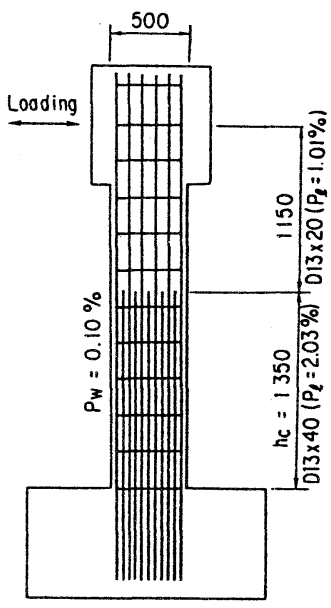

(c) Specimen $\mathrm{P}-15$



(d) Specimen P-16

Fig. 1 Specimens Used for Loading Test

い, 宮城県沖地震及び浦河沖地震による実橋脚の被 害を加味して，簡便な主鉄筋段落し部の耐震判定法 の提案を行った. その後, 最近発生した平成5年釧 路沖地震及び平成5年北海道南西沖地震による9橋の 鉄筋コンクリート橋脚主鉄筋段落し部の損傷をもと に，提案法の妥当性を検証した.

\section{2. 鉄筋コンクリート橋脚模型の載荷実験}

\section{（1）実験供試体}

実験に用いた鉄筋コンクリート橋脚模型の構造諸 元を Table 1に示す ${ }^{5)}$. これらは, 主鉄筋の定着長 の影響を定量的に評価できるように配慮して製作さ れたものである。例えば，Fig.1に示す供試体P-10 及びP-14〜P-16は，断面形状やせん断支間比，帯
鉄筋比を一定として，段落し鉄筋の定着長のみを変 化させたものである. すなわち，供試体P-10では 主鉄筋の段落しを行っていない，供試体P-14では, 計算上段落ししてよい位置で主鉄筋量を基部の $1 / 2$ に減らした。したがって，主鉄筋の定着長は全くな いことになる，供試体P-15及びP-16では，計算上 段落ししてよい位置から，それぞれ，断面の幅の $1 / 2$ 倍 $(25 \mathrm{~cm})$ 及び 1 倍 $(50 \mathrm{~cm})$ だけ高い位置で主鉄筋量 を基部の $1 / 2$ に減らした。したがって，主鉄筋の定



これらの供試体では，帯鉄筋比は $0.10 \%$ 一定値 とした.この值は，現在の道路橋示方書IV下部構造


小さいが，これは，本実験供試体が，段落し主鉄筋 の定着長が問題となる昭和55年以前に設計された鉄 
Table 2 Failure Mode and Seismic Evaluation Factors for Test Specimens

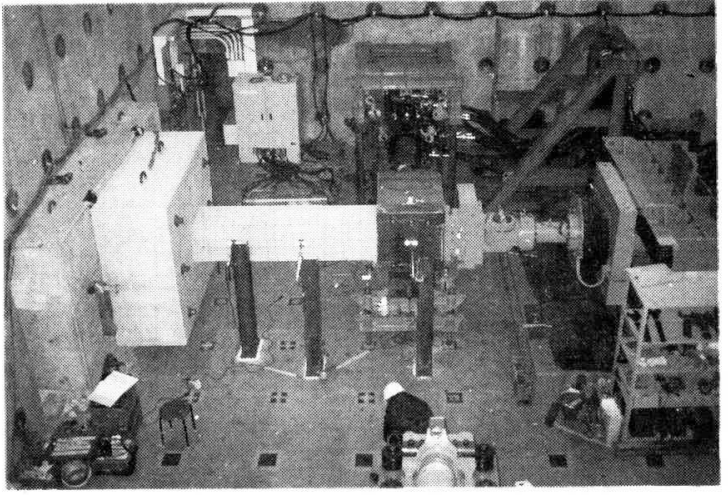

Photo 1 Setup of Cyclic Loading Test

筋コンクリート橋脚をモデルとしており，帯鉄筋比 についても，当時の設計基準レベルに整合させたた めである.

なお，供試体番号は，著者らが実施した一連の鉄 筋コンクリート橋脚模型の交番載荷実験の通し番号 であるため, 必ずしも連続していない.

実験は, Photo 1 に示すように鉄筋コンクリート 橋脚模型を横倒しにし，上部構造の自重に相当する 軸力を作用させた状態で慣性力に相当する水平力を 正負交番載荷した．橋脚基部で主鉄筋が降伏(実験 に基づき降伏ひずみを $1800 \times 10^{-6}$ とした)する時に 荷重作用位置に生じる変位を降伏変位 $\delta y$ と定義し, この整数倍の変位 $n \times \delta y(n=1,2,3 \cdots)$ で順次変位振幅 を増加させながら載荷した。なお，同一の載荷変位 振幅における繰り返し回数は10回とした.

\section{（2）破壊性状}

各実験供試体の損傷位置をTable 2に示す. なお, 表中には後述する損傷形態判別係数 $S$, 段落し部で の耐震安全率 $F_{y}{ }^{T}$, 平均せ九断応力度の解析結果屯 示している.

実験結果の一例として, 供試体P-10及びP-14 P-16の各載荷ステップ終了後における載荷方向と 平行な面の損傷の進展状況をFig.2 Fig.5に示す. 主鉄筋の定着長が全くない供試体 $\mathrm{P}-14$ では， $1 \delta y$ 載荷によって橋脚全面に水平の曲げひびわれが生じ た. $2 \delta$ 載荷で段落し部の曲げひびわれが進展し, 載荷方向と平行な面では段落し部に斜めひびわれが 発生した. $3 \delta$ 載荷では段落し部の斜めひびわれが 進展し，かぶりコンクリートが剥離し始めた. $4 \delta y$

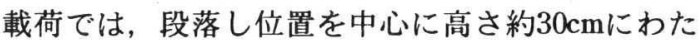
ってかぶりコンクリートが剥落した. $5 \delta$ y載荷にな ると，段落し部においてかぶりコンクリートの剥落

\begin{tabular}{|l|c|c|c|l|}
\hline $\begin{array}{c}\text { Speci- } \\
\text { men }\end{array}$ & $\begin{array}{c}\text { Failure } \\
\text { Mode } \\
\text { Factor S }\end{array}$ & $\begin{array}{c}\text { Safety } \\
\text { Factor } \\
\text { Fy }^{\mathrm{T}}\end{array}$ & $\begin{array}{c}\text { Average } \\
\text { Shear Stress } \\
(\mathrm{MPa})\end{array}$ & $\begin{array}{c}\text { Location } \\
\text { of } \\
\text { Failure }\end{array}$ \\
\hline $\mathrm{P}-14$ & 0.78 & 0.90 & 0.39 & Termination \\
\hline $\mathrm{P}-15$ & 0.91 & 1.05 & 0.39 & $\begin{array}{l}\text { Base and } \\
\text { Termination }\end{array}$ \\
\hline $\mathrm{P}-16$ & 1.10 & 1.27 & 0.39 & Base \\
\hline $\mathrm{R}-1$ & 0.90 & 1.12 & 0.25 & Termination \\
\hline $\mathrm{R}-2$ & 0.98 & 1.22 & 0.25 & $\begin{array}{l}\text { Base and } \\
\text { Termination }\end{array}$ \\
\hline $\mathrm{R}-3$ & 1.07 & 1.33 & 0.25 & Base \\
\hline $\mathrm{R}-4$ & 0.69 & 0.73 & 0.86 & Termination \\
\hline $\mathrm{R}-8$ & 0.80 & 1.08 & 0.29 & Termination \\
\hline $\mathrm{R}-12$ & 0.79 & 1.05 & 0.34 & Termination \\
\hline $\mathrm{R}-13$ & 0.88 & 1.19 & 0.40 & Termination \\
\hline $\mathrm{R}-14$ & 0.88 & 1.17 & 0.25 & Termination \\
\hline $\mathrm{R}-15$ & 0.84 & 0.99 & 0.19 & Termination \\
\hline
\end{tabular}

が進展し，主鉄筋が 2 本破断した. $6.5 \delta$ y載荷では 段落しされていない20本の主鉄筋のうち8本が破断 し，ここで載荷を終了した，なお，基部周辺におい ては損傷はほとんど生じなかった。

供試体 $\mathrm{P}-14$ の破壊の進展状況より, 段落し部で の損傷のメカニズムを推定すると次の通りである. すなわち，まず，段落し部で断面を貫通する水平方 向の曲げひびわれが発生し，これにより，コンクリ 一トが負担できるせん断抵抗力が失われる. そのた めに，さらに載荷を進めると，斜めひびわれが進展 してゆき, 最終的には段落し部でせん断破壊の形態 を呈したものと考えられる.

一方，主鉄筋の定着長を断面幅の $1 / 2$ とした供試 体 $\mathrm{P}-15$ では, $1 \delta$ y載荷では供試体 $\mathrm{P}-14$ と同様に水 平の曲げひびわれが生じた. $2 \delta$ 載荷で段落し部の 曲げひびわれが進展するとともに，斜めひびわれも 発生した. $3 \delta$ y載荷になると段落し部の斜めひびわ れが進展するとともに，基部にも斜めひびわれが生 じ始めた. $4 \delta y$ 載荷では，段落し部と基部の斜めひ びわれがともに増加したが, $5 \delta$ y載荷になると基部 から20 40cmの範囲でかぶりコンクリートの剥離 が生じた. $6 \delta y$ 載荷以降になると基部にのみ損傷が 集中し， $8.5 \delta$ y載荷で，基部における 40 本のうち 24 本の主鉄筋が破断した.

主鉄筋の定着長を断面幅の1倍とした供試体 $\mathrm{P}-16$ 及び段落しをしていない供試体P-10はほぼ同様な 破壊形態となった. すなわち, $3 \delta$ y載荷で基部にお いて曲げひびわれが顕著となり，4 $\delta$ y載荷で基部か ら約 $30 \mathrm{~cm}$ 高さにわたりかぶりコンクリートが剥 離した. その後, 基部のかぶりコンクリートの剥離 が順次進展し，8 $\delta$ y載荷では累計で11本 $(\mathrm{P}-10)$ 及び 10本(P-16)の主鉄筋が破断し，最終的に基部で曲 げ破壊した．また，段落し部周辺には損傷はほとん 
$\stackrel{\text { Loading }}{\longleftrightarrow}$

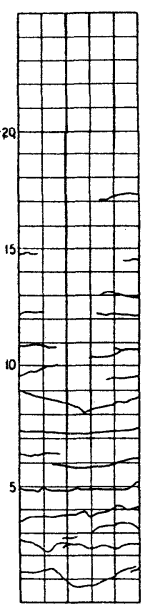

$1 \delta y$

Loading



Loading
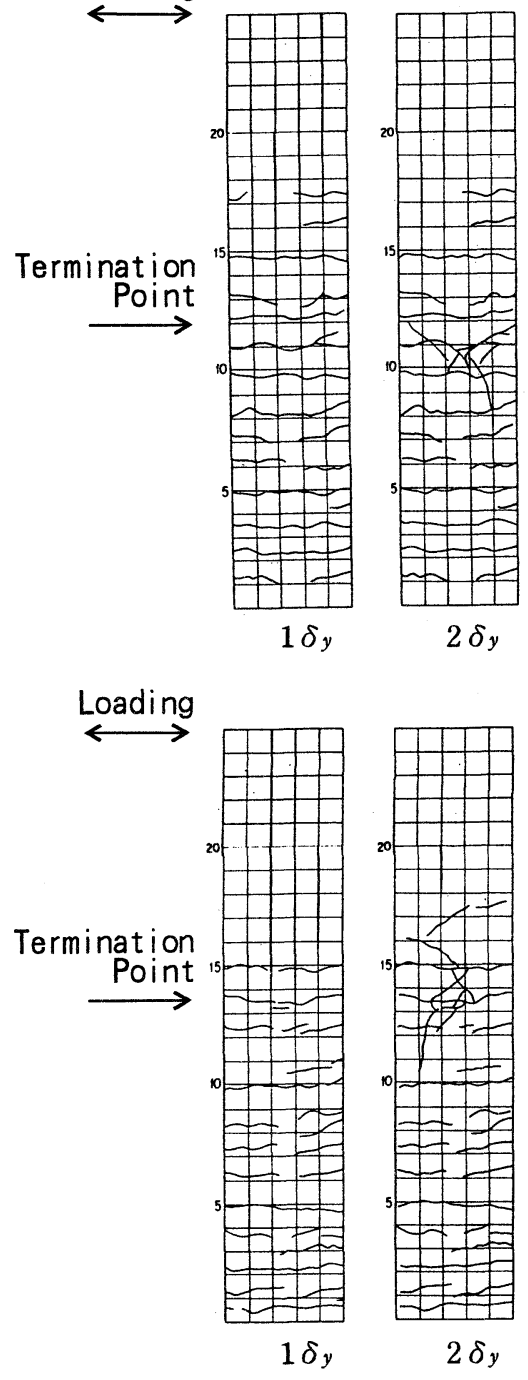
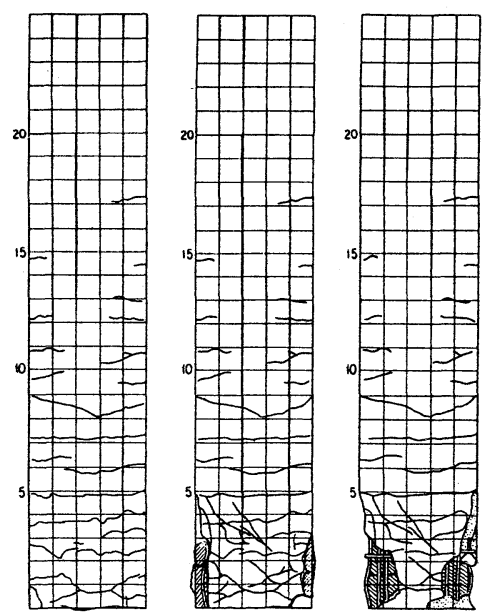

$$
3 \delta y
$$

$4 \delta y$

$5 \delta y$
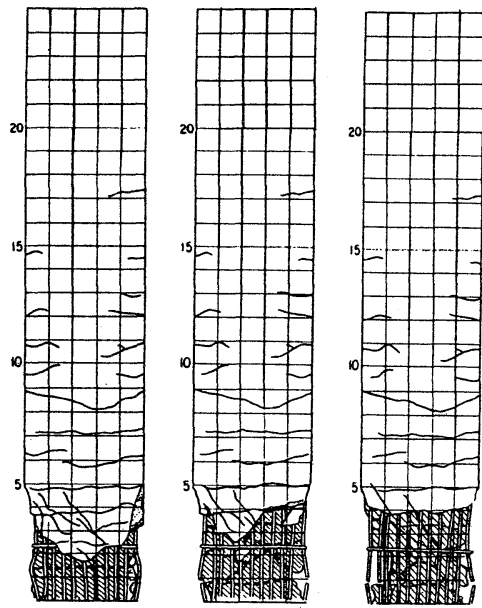

$6 \delta y$

$7 \delta y$

$8 \delta y$

Fig. 2 Failure Mode of Specimen P-10
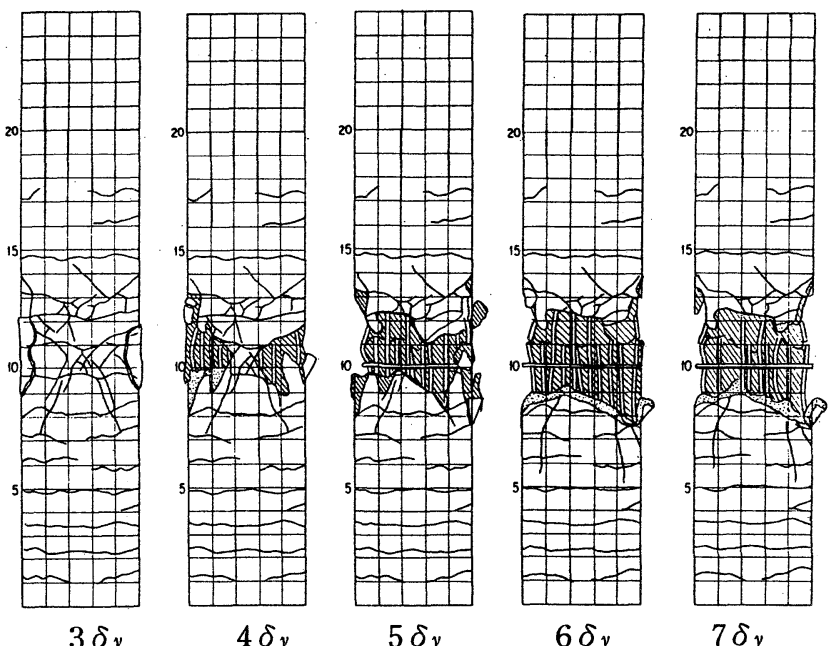

Fig. 3 Failure Mode of Specimen P-14

$6 \delta y$

$7 \delta y$

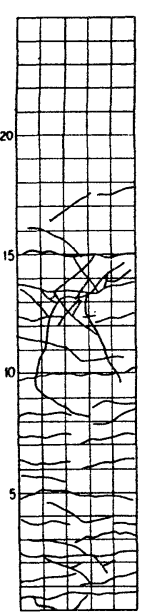

$$
3 \delta y
$$

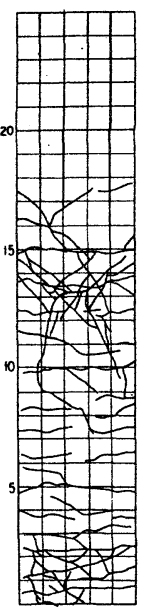

$4 \delta y$

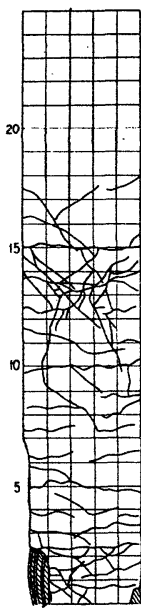

$5 \delta y$

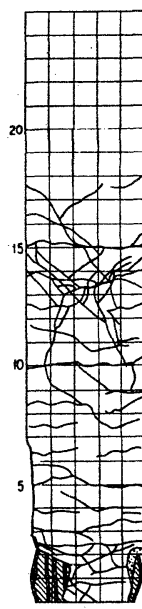

$6 \delta y$

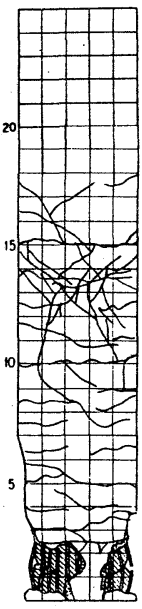

$7 \delta y$

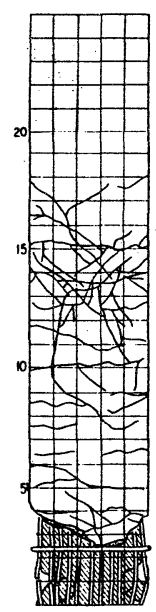

$8.5 \delta y$

Fig. 4 Failure Mode of Specimen $\mathrm{P}-15$ 


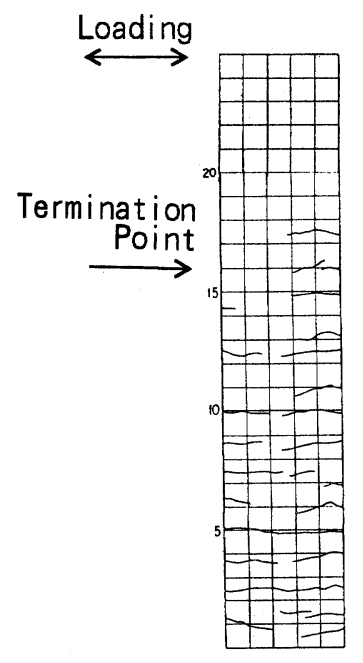

$1 \delta y$

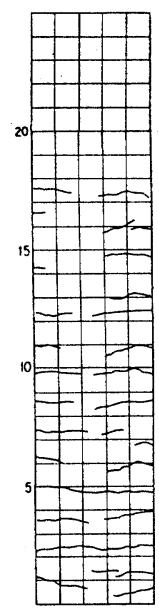

$2 \delta y$

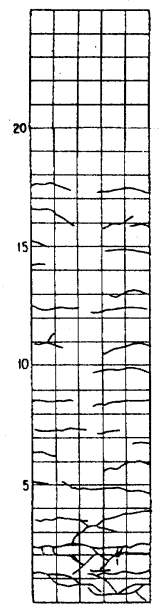

$3 \delta y$



$4 \delta y$

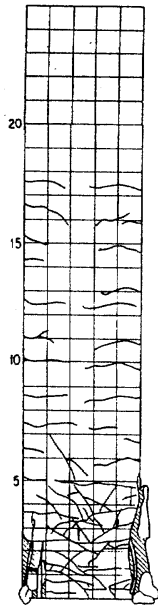

$5 \delta y$

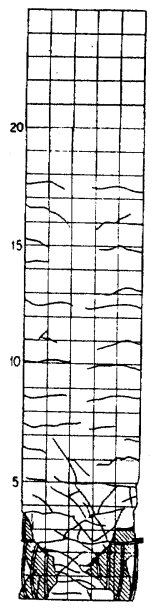

$6 \delta$ y

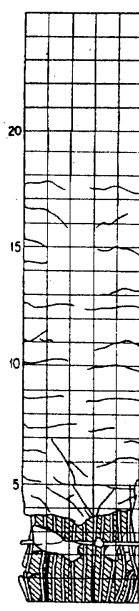

$7 \delta y$

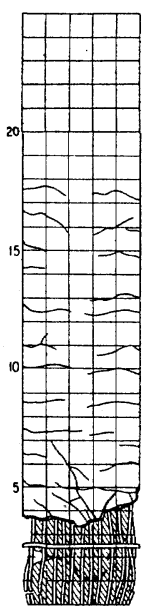

$8 \delta y$

Fig. 5 Failure Mode of Specimen P-16

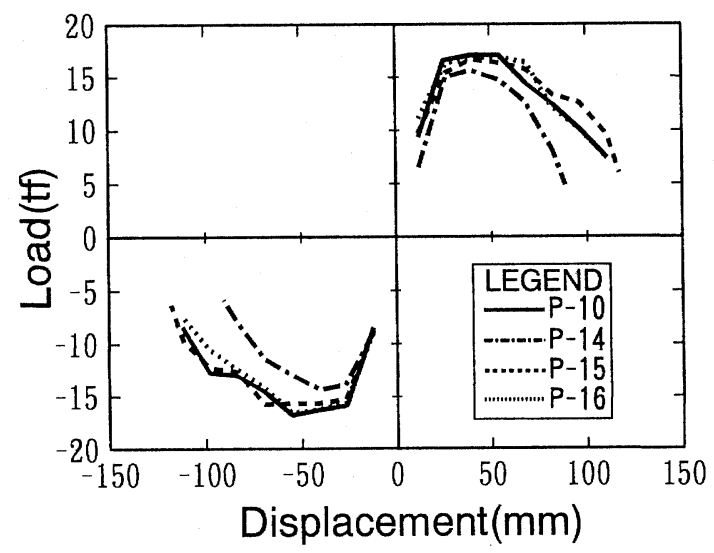

Fig. 6 Envelopes of Lateral Load vs. Displacement Hysteresis Loops

ど生じなかった.

このように，主鉄筋の定着長を $0 \mathrm{~cm}$ とた供試体 P-14では段落し部でせん断破壊し，定着長を断面 幅の半分とした供試体P-15では段落し部にも損傷 が生じたが最終的には基部で，また，定着長を断面 幅の1倍とした供試体P-16では基部でそれぞれ曲げ 破壊した．また，段落し部で破壊する場合には，基 部で破壊する場合よりも早い載荷段階で, コンクリ 一トの剥離及び主鉄筋の破断が生じた.

\section{（3）耐力及び変形性能}

Fig.6は, 供試体P-10及びP-14 P-16の橋脚天 端における水平荷重と水平変位の履歴曲線をその包 絡線によって比較したものである.これより，最終 的に基部で破壊したP-15及びP-16の包絡線は, 段 落しのないP-10とほぼ同様な挙動を示すことがわ
かる. ただし，P-15では段落し部と基部の2筒所で 損傷が生じており, 塑性ヒンジが増えるという観点 から，これは耐震上は望ましくない破壊形態である. 一方, 段落し部で破壊したP-14は, 最大耐力が他 の供試体よりも小さく, また最大耐力後の耐力低下 も著しいことがわかる. 段落し部で破壊した他の供 試体においても, 同様な傾向が認められた. したが って, 耐震性能の観点からは, 段落し部で損傷させ ないことが重要と言える.

\section{3. 主鉄筋段落し部の耐震判定法}

前述した実験結果から，主鉄筋段落し部でのせん 断破壊では，その損傷進展の第一ステップとして水 平方向の曲げひびわれが生じることが明らかである. このことは, 釧路沖地震や北海道南西沖地震におけ る主鉄筋段落し部の損傷形態を見ても ${ }^{2)}{ }^{3)}$ ，水平ひ びわれのみの損傷, 水平ひびわれ之斜めひびわれが 混在する損傷，主鉄筋が座屈している損傷等に分類 でき, 段落し部での初期の損傷状態として, 曲げひ びわれが生じていることからも裏付けられる.した がって，主鉄筋段落し部の耐震性を判定するために は，段落し部での曲げ損傷の可能性を正しく評価す ることが重要と言える.そこで，Fig.7に示される ような損傷形態判別係数 $S$ 導入する. すなわち, 損傷形態判別係数Sは, 橋脚基部之段落し部のいず れで先に曲げ損傷が生じるかを定量的に判定するこ とを意図として定義した指標であり，段落し部及び 橋脚基部において, 設計曲げモーメントに対する降 伏曲げモーメントの比 $F_{y}{ }^{T}, F_{y} B$ を用いて次式で定義 する. 


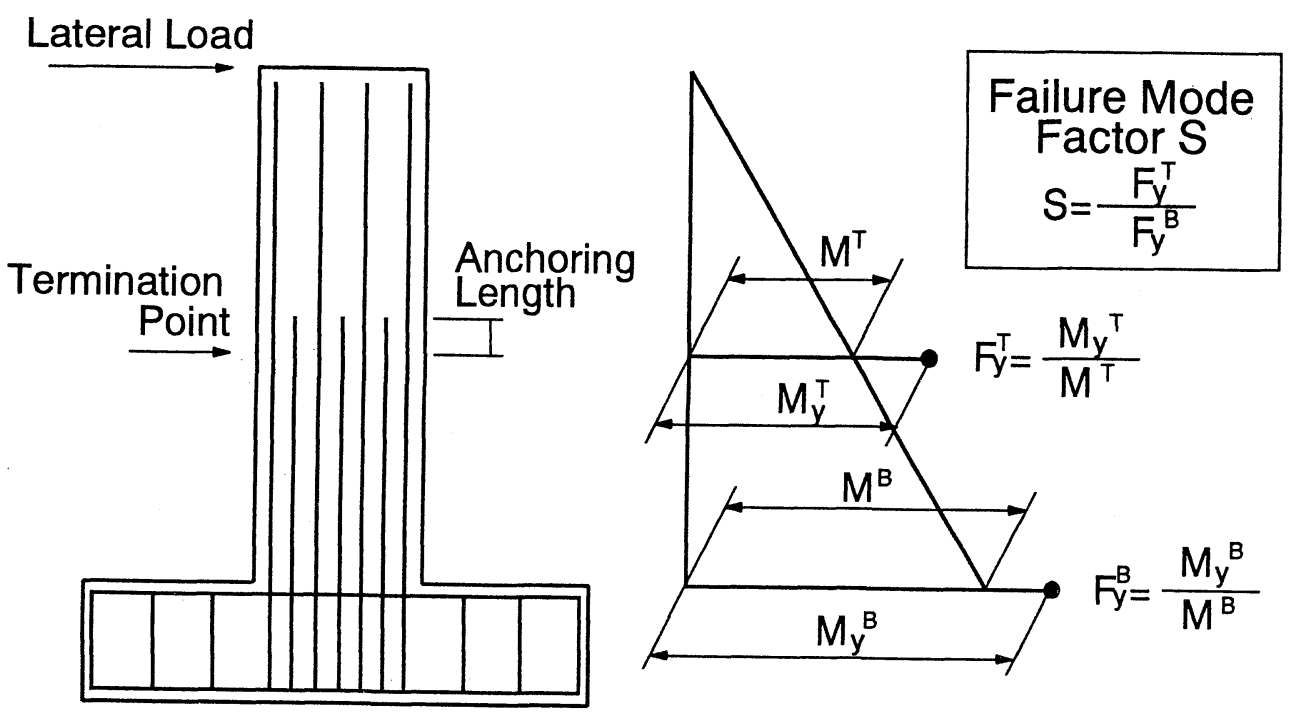

Fig. 7 Definition of Seismic Evaluation Factors

$$
\text { ここに, } \quad \begin{aligned}
S & =\frac{F_{y} T}{F_{y}{ }^{B}} \\
F_{y} T & =\frac{M_{y} T}{M^{T}} \\
F_{y} B & =\frac{M_{y}{ }^{B}}{M^{B}}
\end{aligned}
$$

$M_{y}{ }^{T}, M_{y}{ }^{B}$ ：段落し位置及び基部における断面の降 伏曲げモーメント

$M^{T}, M^{B}$ : 設計地震力を作用させた時に段落し位置 及び基部に生じる曲げモーメント

以下, $F_{y}{ }^{T}, F_{y}{ }^{B}$ をそれぞれ段落し位置及び基部にお ける耐震安全率と呼ぶ.

したがって，基本的には損傷形態判別係数が 1.0 未満であれば, 設計地震力に対して段落し部が確保 している耐震安全率が基部よりも小さいことになり, 曲げ損傷は段落し部の方で先行して生じることを意 味する.ただし，段落しされている主鉄筋が断面に 対して有効に機能するためには, 所定の定着長が必 要であるため, 損傷形態判別係数の算定においては, 段落し位置を実際の高さから主鉄筋の定着長分だけ 低い位置で定義するものとする．ここでは，主鉄筋 の定着長は, 道路橋示方書IV下部構造編 ${ }^{11)}$ に準拠 して求める.

一方, 設計で考慮している地震力に対してある程 度以上の耐力を有していれば, 損傷が段落し部で先 行するとしても損傷の程度は小さく, 落橋といった 致命的な被害には至らないとみることができる. そ こで, 損傷形態判別係数Sによる判定に加えて, 式
(2)で算出される $F_{y} T$ により，段落し部に生じる損傷

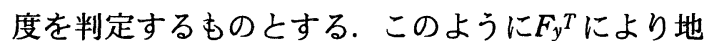
震時に生じる損傷の程度が推定できれば，耐震補強 の優先度を評価する場合に屯活用できると考えられ る.

さらに，先述の実験結果を見ると，段落し部で損 傷した供試体では，最初に水平の曲げひびわれが発 生し，その後斜めひびわれに進展して最終的なせん 断破壊に至っている. したがって，段落し部で曲げ 損傷が先行するものについては，せん断応力につい ても照査しておく必要がある.

\section{4. 耐震判定基準の提案}

上述した耐震判定法では，段落し部での損傷の可 能性やその程度を評価するために，損傷形態判別係 数 $S$ 及び段落し部での耐震安全率 $F_{y}{ }^{T}$ に対してある 判定基準值を設定する必要がある. そこで, Table 2に示した鉄筋コンクリート橋脚模型の正負交番載 荷実験結果を基に，これらの判定基準値を定めるこ とにする.

Fig.8は，式(1)を適用して解析した各供試体の損 傷形態判別係数 $S$ 之実験で生じた破壊モードの関係 を示したものである.ここには，段落し部に損傷を 受けた浦河沖地震による静内橋 $\mathrm{P} 3$ 橋脚 ${ }^{1)}$ 及び宮城 県沖地震による新江合橋P3橋脚 ${ }^{12)}$ の解析結果も加 えている ${ }^{5)}$ 。これより，実験結果からは，Sが1.0以 下の橋脚で段落し部に損傷が生じることがわかる. 一方, 新江合橋ではSが1.08となっており, 模型供 


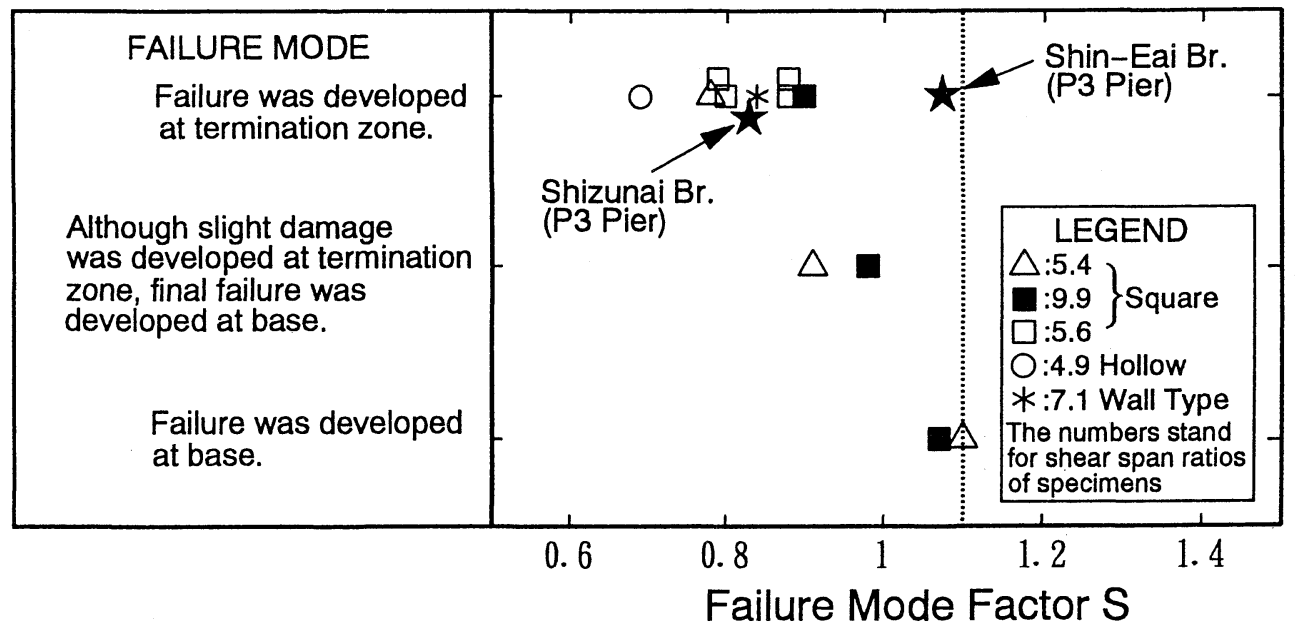

Fig. 8 Evaluation of Failure Mode in Terms of Failure Mode Factor S

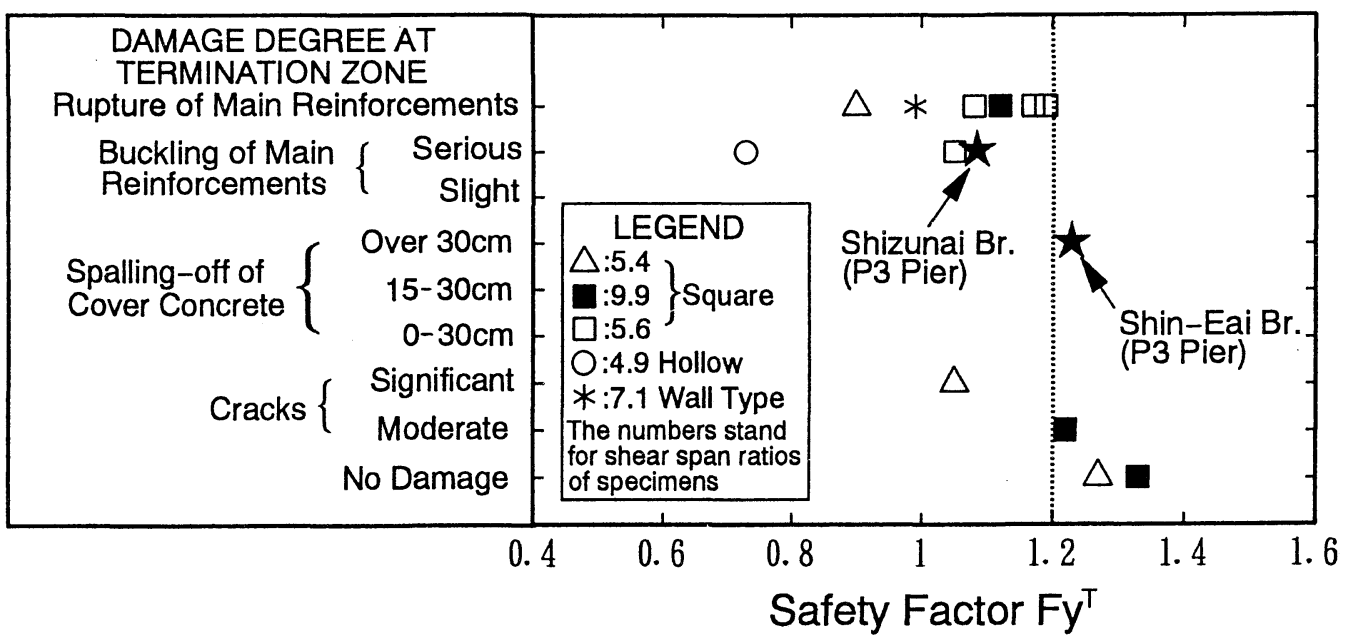

Fig. 9 Evaluation of Damage of Model Pier after $5 \delta y$ Loading in Terms of Safety Factor $F_{y} T$

試体による実験結果のみから判断すれば，基部で曲 げ破壊することが予測される領域にある. しかしな がら, 実際には新江合橋では段落し部で被りコンク リートが剥離し，主鉄筋が露出するという損傷が生 じた. そこで，この被害事例を考慮に入れ，主鉄筋 の段落し位置において損傷が生じるか否かを $S=1.1$ を基準として判定することを提案する.これは，後 述する釧路沖地震や北海道南西沖地震による被害の 解析からむ妥当な判断であることが, あとから裹付 けられた.

Fig.9は，式(2)より算定される $F_{y}{ }^{T}$ と段落し部にお ける損傷度の関係を示したものである.ここで，段 落し部における損傷度は, $5 \delta$ 載荷後における損傷 の程度を用いることとした．これより，段落し部に おいて, 主鉄筋の著しい座屈や破断といった落橋に つながる著しい損傷の生じる可能性のある橋脚は,
いずれも $F_{y}^{T}$ が1.2未満で生じていることがわかる. そこで，ここでは，段落し部に生じる被害の程度を $F_{y}{ }^{T}=1.2$ を基準として判定するものとする.

なお，各供試体ではコンクリートの設計基準強度 が $300 \mathrm{kgf} / \mathrm{cm}^{2}$ であることから, 許容せん断応力度は 道路橋示方書IV下部構造編 ${ }^{11}$ によれば $4.5 \mathrm{kgf} / \mathrm{cm}^{2}$ となる. Table 2 によれば, R-4供試体のようにコ ンクリート断面を大きく校った橋脚では, 橋脚に作 用する平均せん断応力度は許容せん断応力度を大き く上回ることがわかる.

以上の検討結果より, 主鉄筋段落し部の耐震判定 法をFig.10のように提案する ${ }^{5)}$. ただし, 本耐震判 定法は，せん断支間比が2.0よりも大きい橋脚を対 象とする.これは，せん断支間比が2.0以下の橋脚 では，一般に高さが低く，主鉄筋の段落しが行われ ない場合が多いためである. 


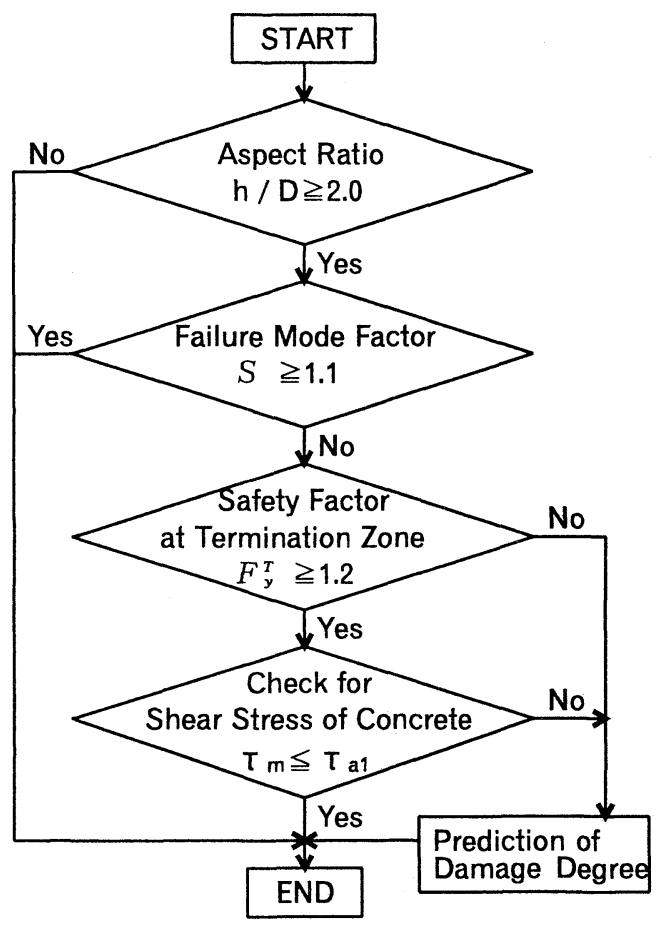

(a) Procedure of Seismic Evaluation

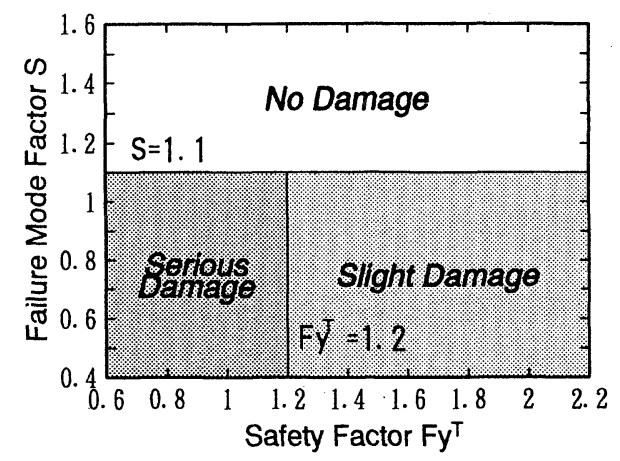

(b) Prediction of Damage Degree

Fig. 10 Seismic Evaluation Method Proposed

\section{5. 釧路沖地震及び北海道南西沖地震による 主鉄筋段落し部の被害解析}

\section{（1）解析対象とした鉄筋コンクリート橋脚}

平成5年の釧路沖地震及び北海道南西沖地震では, 9橋において鉄筋コンクリート橋脚の段落し部に損 傷が生じた. 両地震による実被害を基に，Fig.10に 示した段落し部に対する耐震判定法の妥当性を検証 する.

解析対象とした鉄筋コンクリート橋脚は, Table 3に示す 12 橋の中の 14 基である ${ }^{13)}$ 。これらは釧路 沖地震及び北海道南西沖地震で主鉄筋段落し部に被 害が生じた9基と，その近くに位置しながら無被害
であった 5 基の鉄筋コンクリート橋脚である. 同一 橋梁で複数の橋脚に損傷を生じたものもあるが, こ の場合には，最も損傷度が大きかった橋脚に対して 解析を行うこととした. なお，新知内橋は，Photo 2に示すように，同一橋梁区間内に，昭和45年に建 設された橋脚群と河川改修に伴い平成元年に建設さ れた橋脚群が混在しており, 新旧の基準で設計され た橋脚の耐震性を比較する上で大変興味深い ${ }^{14}$ ，

解析に用いた諸条件をTable 4 に示す. なお，こ れらの值には一部不明なものもあったが，当時の設 計実績に基づいて設定した ${ }^{13)}$ 。 また, 設計震度は, 各橋梁の設計当時の值を用いた. 解析における地震 力の作用方向は，断面設計に支配的な方向とした. したがって，単純橋の場合，円形断面では橋軸直角 方向, 小判型断面では橋軸方向である.

\section{（2）解析結果}

Fig.11は, 解析結果の一例として新知内橋P3橋脚 及び新 $\mathrm{P} 2$ 橋脚の降伏曲げモーメント亡設計地震力 による曲げモーメントを比較して示したものである. これより，昭和 45 年に建設されたP3橋脚では，基 部での耐震安全率 $F_{y}{ }^{B}$ と比較して, 段落し位置での 耐震安全率 $F_{y} T$ は小さく，損傷形態判別係数 $S$ は, 1 段目の段落し部では0.86，2段目の段落し部では0.81 となった.これは，Fig.10に提案した段落し部での 損傷の可能性を判定する基準値1.1よりも小さく, また，各段落し位置での耐震安全率 $F_{y} T$ も基準値の 1.2未満であることから，段落し部で著しい損傷が 生じると判定されることになる．本橋脚では， Photo 3 に示すように，主鉄筋の座屈に至る被害が 生じていることから，Fig.10による判定結果とよく 一致している. 一方, 昭和55年の新しい基準で設計 された新P2橋脚では，損傷形態判別係数Sが1.15で あり，Fig.10によれば段落し部では損傷が生じない と判定される.これは，本橋脚が無被害であったこ とと一致している.

各解析対象橋脚に対して同様な計算を行い，損傷 形態判別係数 $S$ 及び段落し部での安全率 $F_{y}{ }^{T}$ を算定 した結果をまとめるとTable 5の通りである.

\section{（3）耐震判定法の適用}

Fig.12は, Table 5に示した損傷形態判別係数 $S$ と 実際に生じた損傷度の関係を示したものである.こ こで，実際の被害は，(1)主鉄筋の破断，(2)主鉄筋の 著しい座屈，(3)主鉄筋の軽微な座屈，(4)斜めひびわ れの発生，(5)水平ひびわれの発生，(6)無被害の6通 りに区分している．また，段落しが2段面にわたっ て行われている橋脚については，損傷形態判別係数 
Table 3 Bridge Piers for Analyses

\begin{tabular}{|c|c|c|c|c|}
\hline \multirow{2}{*}{$\begin{array}{c}\text { Cross } \\
\text { Sectional } \\
\text { Shape }\end{array}$} & \multicolumn{2}{|c|}{ Circular } & \multicolumn{2}{c|}{ Elliptic } \\
\cline { 2 - 5 } & Damaged & Undamage & Damaged & Undamaged \\
\hline $\begin{array}{c}\text { Kushiro-oki } \\
\text { Earthquake }\end{array}$ & $\begin{array}{c}\text { Yoda Br. } \\
\text { Matsunoe Br. } \\
\text { Hatsune Br. } \\
\text { Gojukkoku Br. } \\
\text { Akangawa Br. }\end{array}$ & Sensho Br. & Shintawa Br. & $\begin{array}{c}\text { Takadai Br. } \\
\text { Tsurumi Br. }\end{array}$ \\
\hline $\begin{array}{c}\text { Hokkaido } \\
\text { Nansei-oki }\end{array}$ & $\begin{array}{c}\text { Motoe Br. } \\
\text { Shin-shiruchi Br. } \\
\text { (Old Pier) } \\
\text { Motouriya Br. }\end{array}$ & - & - & $\begin{array}{c}\text { Shin-shiriuchi Br. } \\
\text { (New Pier) }\end{array}$ \\
\hline
\end{tabular}

Table 4 Analytical Parameters

\begin{tabular}{|c|c|l|l|l|c|}
\hline Bridge & Pier & Analyzed & $\begin{array}{c}\text { Seismic } \\
\text { Coefficient } \\
k_{h}\end{array}$ & $\begin{array}{c}\text { Concrete } \\
\begin{array}{c}\text { Strength } \\
\text { (MPa) }\end{array}\end{array}$ & $\begin{array}{c}\text { Material of } \\
\text { Longitudinal } \\
\text { Reinforcement }\end{array}$ \\
\hline Yoda Br. & P1 & Transversal & $0.20^{*}$ & 20.6 & SD295 \\
\hline Matsunoe Br. & P3 & Transversal & 0.20 & 17.7 & SD235 \\
\hline Hatsune Br. & P4 & Transversal & 0.20 & 20.6 & SDC390 \\
\hline Shintawa Br. & P2 & Longitudinal & 0.20 & 20.6 & SD295 \\
\hline Gojukkoku Br. & P1 & Transversal & 0.20 & 20.6 & SDC390 \\
\hline Akangawa Br. & P1 & Transversal & $0.20^{*}$ & 20.6 & SD345 \\
\hline \multirow{2}{*}{ Sensho Br. } & P4 & Longitudinal & 0.18 & 20.6 & SD295 \\
\cline { 2 - 6 } & P5 & Transversal & 0.18 & 20.6 & SD295 \\
\hline Takadai Br. & P2 & Longitudinal & 0.24 & 20.6 & SD295 \\
\hline Tsurumi Br. & P5 & Longitudinal & 0.24 & 20.6 & SD295 \\
\hline Motoe Br. & P3 & Transversal & 0.20 & 20.6 & SDC390 \\
\hline Shin-shiriuchi & P3 & Transversal & 0.15 & 20.6 & SD295 \\
\cline { 2 - 6 } Br. New P2 & Longitudinal & 0.14 & 20.6 & SD295 \\
\hline Motouriya Br. & P1 & Transversal & $0.15^{*}$ & 20.6 & SR235 \\
\hline
\end{tabular}

*) assumed from the past records



Photo 2 Shin-shiriuchi Bridge

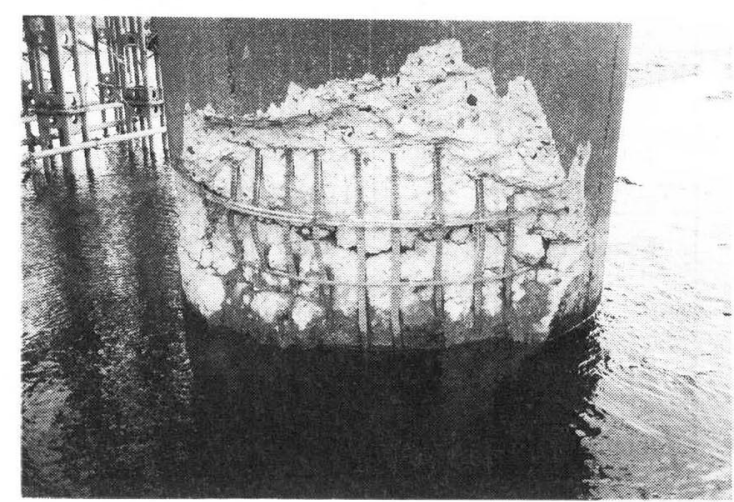

Photo 3 Damage of Shin-shiriuchi Bridge (P3)
Sが小さい方の断面に対する結果を示している. こ れは, 後述する2段の段落し之損傷位置の関係に対 する検討により, 損傷形態判別係数Sが小さい方の 断面で損傷が生じることが明らかになったためであ る.これより, 損傷形態判別係数Sが小さくなるに つれて，損傷度が大きくなることがよくわかる．ま
た，実際に段落し部で損傷した橋脚は，損傷形態判 別係数Sがいずれも1.1未満である. 一方, 昭和 55 年 以後の新しい基準で設計された橋脚ではいずれも $S$ は1.1以上となる.これは, Fig.10に示した損傷形 態判別係数に対する判定基準値が適切であることを 示している. 

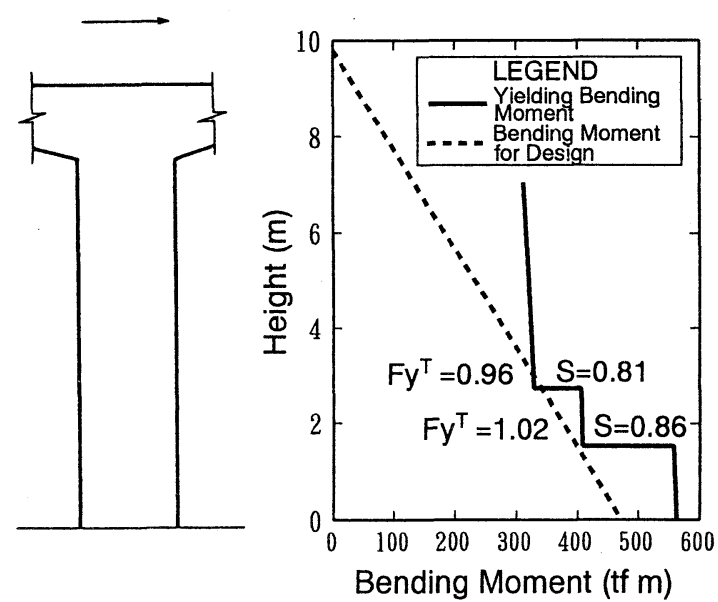

(a) Pier P3

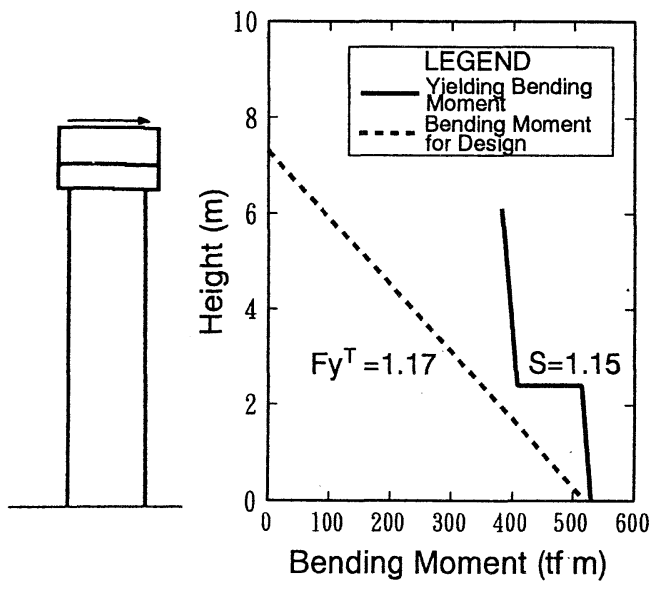

(b) New Pier P2

Fig. 11 Seismic Evaluation for Shin-shiriuchi Bridge

Table 5 Damage Degree Predicted by Fig. 10 and Actual Damage Caused by Kushiro-oki Earthquake and Hokkaido-nansei-oki Earthquake

\begin{tabular}{|c|c|c|c|c|c|c|c|c|}
\hline \multirow{2}{*}{ Bridge } & \multirow{2}{*}{\multicolumn{2}{|c|}{ Pier }} & \multicolumn{2}{|c|}{$\begin{array}{l}\text { Yielding Bending } \\
\text { Moment }(\mathrm{t} \cdot \mathrm{m})\end{array}$} & \multicolumn{2}{|c|}{ Safety Factor } & \multirow{2}{*}{$\begin{array}{l}\text { Failure } \\
\text { Mode } \\
\text { Factor } \\
\quad S\end{array}$} & \multirow{2}{*}{ Damage Degree } \\
\hline & & & $\begin{array}{l}\text { Base } \\
M_{y}{ }^{B}\end{array}$ & $\begin{array}{c}\text { Termination } \\
M_{y}{ }^{T}\end{array}$ & $\begin{array}{l}\text { Base } \\
F_{y}{ }^{B}\end{array}$ & $\begin{array}{c}\text { Termination } \\
F_{y}{ }^{T}\end{array}$ & & \\
\hline \multirow{2}{*}{ Yoda Br. } & \multirow{2}{*}{ P1 } & 1st & \multirow[b]{2}{*}{218.3} & 148.9 & \multirow[b]{2}{*}{1.24} & 0.87 & 0.70 & No Damage \\
\hline & & 2nd & & 111.9 & & 0.74 & 0.60 & $\begin{array}{l}\text { Rupture and Serious Buckling } \\
\text { of Longitudinal Reinforcement }\end{array}$ \\
\hline Matsunoe $\mathrm{Br}$. & \multicolumn{2}{|c|}{ P3 } & 962.4 & 760.7 & 1.96 & 2.01 & 1.03 & $\begin{array}{l}\text { Slight Buckling of } \\
\text { Longitudinal Reinforcement }\end{array}$ \\
\hline Hatsune $\mathrm{Br}$. & \multicolumn{2}{|c|}{ P4 } & 657.4 & 433.8 & 1.51 & 1.15 & 0.76 & Diagonal Crack \\
\hline Shintawa Br. & \multicolumn{2}{|c|}{ P2 } & 358.6 & 201.3 & 1.02 & 0.92 & 0.90 & Horizontal Crack \\
\hline Gojukkoku Br. & \multicolumn{2}{|c|}{ P1 } & 915.8 & 634.4 & 1.26 & 1.12 & 0.89 & Slight Horizontal Crack \\
\hline \multirow{2}{*}{ Akangawa $\mathrm{Br}$. } & & 1st & \multirow{2}{*}{1161.1} & 772.9 & \multirow{2}{*}{1.30} & 1.00 & 0.77 & No Damage \\
\hline & & 2nd & & 551.5 & & 0.87 & 0.67 & Slight Horizontal Crack \\
\hline \multirow{2}{*}{ Sensho Br. } & \multicolumn{2}{|c|}{$\mathrm{P} 4$} & 2193.8 & 1387.6 & 1.09 & 1.34 & 1.23 & No Damage \\
\hline & \multicolumn{2}{|c|}{ P5 } & 1174.6 & 790.3 & 1.08 & 1.31 & 1.21 & No Damage \\
\hline Takadai $\mathrm{Br}$. & \multicolumn{2}{|c|}{ P2 } & 1179.8 & 599.9 & 1.33 & 1.83 & 1.38 & No Damage \\
\hline Tsurumi Br. & \multicolumn{2}{|c|}{ P5 } & 11113.8 & 6089.5 & 1.59 & 1.79 & 1.13 & No Damage \\
\hline Motoe $\mathrm{Br}$. & \multicolumn{2}{|c|}{ P3 } & 425.1 & 294.9 & 1.00 & 0.82 & 0.82 & $\begin{array}{l}\text { Serious Buckling of } \\
\text { Longitudinal Reinforcement }\end{array}$ \\
\hline \multirow{3}{*}{ Shin-shiriuchi } & \multirow{2}{*}{ P3 } & 1 st & \multirow[t]{2}{*}{562.2} & 408.7 & \multirow[t]{2}{*}{1.19} & 1.02 & 0.86 & $\begin{array}{l}\text { Serious Buckling of } \\
\text { Longitudinal Reinforcement }\end{array}$ \\
\hline & & 2nd & & 325.6 & & 0.96 & 0.81 & No Damage \\
\hline & New & $\mathrm{P} 2$ & 530.2 & 407.5 & 1.02 & 1.17 & 1.15 & No Damage \\
\hline Motouriya $\mathrm{Br}$. & & P1 & 184.7 & 141.0 & 1.08 & 1.01 & 0.94 & $\begin{array}{l}\text { Serious Buckling of } \\
\text { Longitudinal Reinforcement }\end{array}$ \\
\hline
\end{tabular}

Fig.13は，段落し部での耐震安全率 $F_{y} T$ と実際に 生じた損傷度の関係を示したものである.これより， $F_{y}^{T}$ が小さいほど，損傷度が著しくなることがわか る. また，Table 5 に示したように，大被害を生じ た依田橋，基栄橋，新知内橋，元瓜谷橋では，計算 によって求めた $F_{y}^{T}$ は0.74 1.02であり, Fig.10に示 した著しい損傷の生じる可能性のある $F_{y}{ }^{T}$ の基準値
1.2を下回っている.

ただし，松之恵橋についてだけは段落し部での耐 震安全率 $F_{y}{ }^{T}$ が 2.01 と大きく, 設計地震力に対して 十分大きな安全性を確保していたにもかかわらず, 実際には主鉄筋が座屈するといった被害が生じた。 この理由はよくわからないが，隣接桁との衝突によ り, その慣性力が伝わる等, 何らかの理由で橋脚に 


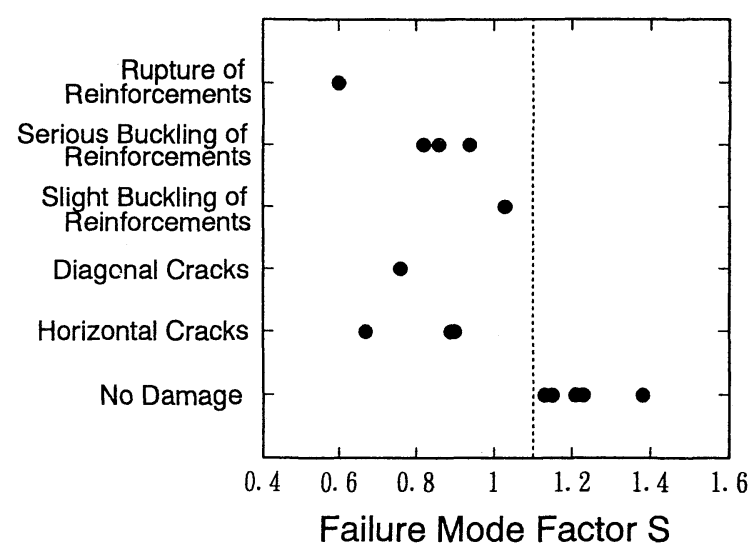

Fig. 12 Effectiveness of Failure Mode Factor

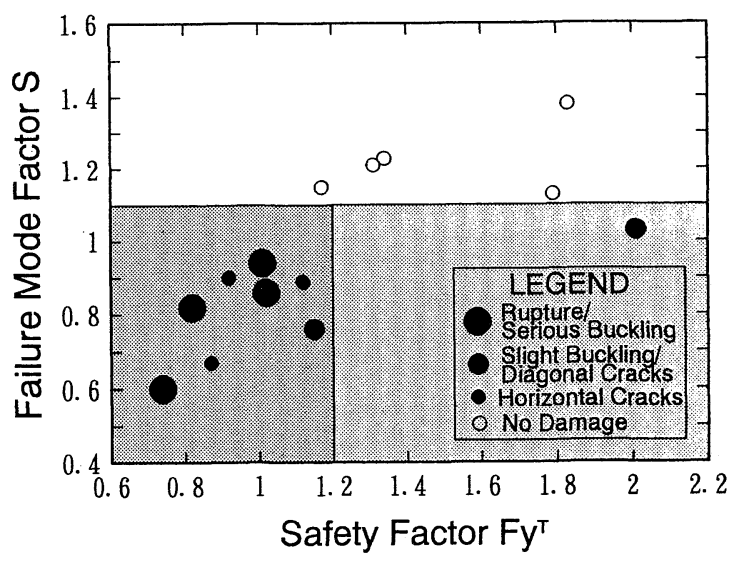

Fig. 14 Effectiveness of the Seismic Evaluation Method

作用した地震力が極めて大きくなったとしか考えら れない，ただし，損傷形態判別係数Sは $1.03 て ゙ あ り ，$ 段落し部での損傷が基部での損傷よりも先行すると 判定されることになる.このため, 設計地震力より 屯大きな地震力が作用すれば，段落し部に被害が生 じる可能性はあることになる.

一方, $F_{y}^{T}$ が1.2未満の場合でも, 斜めひびわれや 水平ひびわれ程度の被害に止まった橋脚もある.こ れは，橋脚に作用した地震力自体が小さかったため であり，もし地震力がもっと大きければ，大被害に 至っていたと考えられる.

Fig.14は，損傷形態判別係数 $S$ 亡段落し部での耐 震安全率 $F_{y} T$ の関係を示したものである．Fig.10に 示した耐震判定法によれば，松之惠橋を除けば，段 落し部で損傷した橋脚は全て著しい損傷が生じる可 能性があると判定されることになる. また, 被害の なかった昭和55年以降の基準で設計された橋脚では,

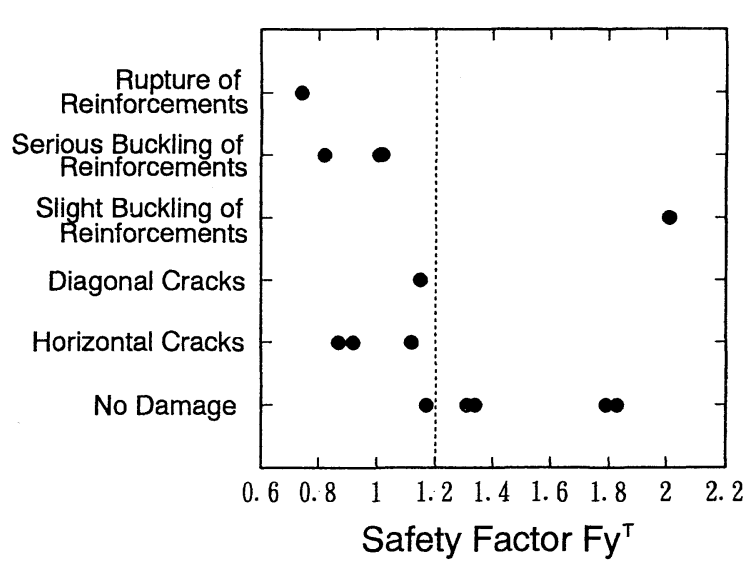

Fig. 13 Effectiveness of Safety Factor
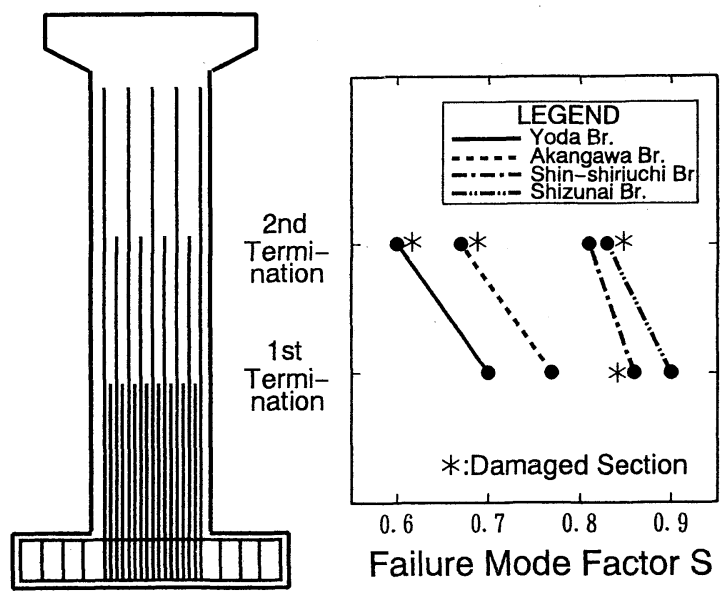

Failure Mode Factor $\mathrm{S}$

Fig. 15 Seismic Evaluation for Piers with Inadequate Anchoring Length at 2 Points

いずれも段落し部では損傷しないと判定されている. 以上の考察より, 本判定手法を適用すれば，段落し 部で損傷が生じる可能性のある橋脚を精度良くに抽 出できると言える.

\section{（4） $2 \mathbf{E} の$ 段落しを有する鉄筋コンクリート橋脚の 耐震性評価}

今回の解析対象とした橋梁の中で，依田橋，阿寒 川橋，新知内橋の各鉄筋コンクリート橋脚では，主 鉄筋の段落しが2段にわたって行われていた．既往 の研究の中で，2段の段落しを有する鉄筋コンクリ 一ト橋脚の耐震性に関する実験的な検討はなく，地 震による損傷断面の推定や段落し部どうしのインタ 一アクションについては，工学的な知見が得られて いない，そこで，これらの3橋と浦河沖地震による 静内橋の被害解析結果を基に，定着長の不十分な主 鉄筋の段落しを2箇所で有する鉄筋コンクリート橋 
脚の耐震性について分析を行った。

Fig.15は，式(1)により算出した段落し断面での損 傷形態判別係数Sを示すと同時に, 実際にどこで損 傷が生じたかを示したものである.これより, 新知 内橋を除く他の 3 橋では, 損傷形態判別係数Sの值 が小さい方の段落し部で損傷が生じていることがわ かる. これは, 単純に損傷形態判別係数Sが小さい 段落し部の方が耐震性が低いためと考えられる.

一方, 新知内橋のP3橋脚では, 被害が生じたの は損傷形態判別係数の大きい1段目の段落し部であ った. この理由は, 1 段目と2段目での損傷形態判別

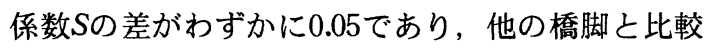
すると小さいことが挙げられる. したがって, どち らの段落し部もほぼ同じような損傷の可能性を有し ていたことを示している. 事実, 新知内橋のP3橋 脚以外の橋脚の損傷を見てみると, P1,P2,P4橋脚の 構造条件はP3橋脚とほとんど同じであるにもかか わらず，損傷はP3橋脚と異なる2段目の段落し部で 生じた.このような事実からも，損傷形態判別係数 Sの差が 0.05 之小さい場合には, 損傷断面を 1 断面に 限定できなくなり，いずれの断面でも損傷する可能 性があると考えるべきであることを示している.

\section{6. 結論}

本文では，段落し鉄筋の定着長をパラメー夕とし た鉄筋コンクリート橋脚模型の正負交番載荷実験を 行い, 段落し部に対する耐震判定法の提案を行った. さらに, 平成 5 年の釧路沖地震及び北海道南西沖地 震において, 主鉄筋段落し部に損傷が生じた鉄筋コ ンクリート橋脚を解析し, 本判定方法の妥当性につ いて検証した. 本研究により得られた結果をまとめ ると, 以下の通りである.

(1)計算上段落ししてよい位置で主鉄筋量を半分に 減らした場合には，損傷は段落し部のみに生じ, また最大耐力後の耐力低下も著しい. また, 段落 し位置をこれよりも断面幅の $1 / 2$ 倍だけ高い位置 とした場合には, 段落し部での損傷が先行して生 じるが, 最終的には基部で破壊する. さらに，段 落し位置を断面幅の1倍まで高くすると, 基部だ けが破壊する.

(2)模型供試体による実験結果と昭和57年の浦河沖 地震による静内橋, 昭和53年の宮城県沖地震によ る新江合橋の被害事例を基に，Fig.10に示す耐震 判定法を提案した.

(3)平成5年の釧路沖地震及び北海道南西沖地震で, 段落し部に損傷が生じた鉄筋コンクリート橋脚の 耐震性をFig.10に基づいて判定した結果，損傷形
態判別係数 $S や$ 段落し部での安全率 $F_{y}^{T}$ が小さく 評価されるにつれ，被害度は大きくなる.

(4)釧路沖地震及び北海道南西沖地震で被災した鉄 筋コンクリート橋脚は, 松之恵橋を除けば全て,

Fig.10に示す耐震判定法により段落し部に著しい 損傷が生じる可能性があると判定される. 松之惠 橋では，段落し部での耐震安全率 $F_{y}^{T}$ は十分大き かったにもかかわらず，段落し部で被害を生じた． この理由はよくわからないが, 損傷形態判別係数 Sは1.1以下であり, そのため, 損傷が基部よりも 段落し部で先行しやすいタイプであった. 隣接桁 の衝突等, 解析に見込んでいない他の条件が被害 に寄与したのではないかと推定される.

(5)損傷形態判別係数 $S$ と段落し部の曲げ降伏に対す る耐震安全率 $F_{y}{ }^{T}$ を用いた耐震判定法により, 主 鉄筋の段落し部で耐震性に劣る鉄筋コンクリート 橋脚を精度よく抽出できる.

(6)定着長の不十分な2段の段落しがある場合には， 基本的には，損傷形態判別係数Sの小さい方の段 落し部で損傷が先行する．ただし，段落し間の損 傷形態判別係数の差が 0.05 之小さい場合には, 損 傷断面を1断面に限定できない。

\section{参考文献}

1) 浅沼秀弥：静内橋地震災害調査，土木技術資料， Vol.25-11, pp.15-20, 1983年11月.

2) 建設省土木研究所 : 1993年釧路沖地震災害調查報告, 土木研究所報告, 第193号, 1994年1月。

3) 建設省土木研究所 : 1993年北海道南西沖地震災害調査 報告, 土木研究所報告, 第194号，1994年7月.

4) 川島一彦, 運上茂樹, 飯田寛之 : 鉄筋コンクリート橋 脚の主鉄筋段落し部における被害実態とその解析, 土 木技術資料，Vol.34-3，pp.33-39，1992年3月.

5) 川島一彦, 運上茂樹, 飯田寛之 : 鉄筋コンクリート橋 脚主鉄筋段落し部の耐震性判定法及び耐震補強法に関 する研究, 土木研究所報告, 第 189 号, 1993年9月.

6) 日本道路協会 : 道路橋示方書 - 同解説IV 下部構造編, 1980年5月.

7) 石橋忠良, 大坪正行, 栗原啓之: 橋脚における鉄筋の 途中定着部の設計，構造物設計資料，No.73，pp.7-14 1983年3月.

8) 山本強, 石橋忠良, 大坪正行, 小林普爾 : 鉄筋を途中 定着した橋脚の耐震性能に関する実験的研究, 土木学 会論文集，第348号/V-1，pp.61-70，1984年8月.

9）尾坂芳夫，鈴木基行，寺澤正人，小林茂敏 : RCはり のせん断耐力に及ぼす引張主鉄筋の途中定着の影響に 関する研究, 土木学会論文集, 第 366 号/V -4 , pp.133-142，1986年2月.

10）尾坂芳夫, 鈴木基行, 宮本幹, 小林茂敏 : 途中定着さ れた引張主鉄筋を有するRCばりのせん断耐力評価之 設計への適用に関する研究，土木学会論文集，第378 号/V-6, pp.89-96, 1987年2月.

11) 日本道路協会 : 道路橋示方書 - 同解説IV下部構造編, 1990年2月. 
12) 建設省土木研究所 : 1978年宮城県沖地震災害調査報告, 土木研究所報告, 第159号, 1983年3月.

13) 川島一彦, 運上茂樹, 星涱順一, 長屋和宏 : 釧路沖地 震及び北海道南西沖地震によるRC橋脚主鉄筋段落し 部の被害とその解析, 土木研究所資料, 第 3283 号, 1994年6月。
14) 川島一彦, 運上茂樹, 星郎順一, 中島燈 : 北海道南西 沖地震による道路橋の被害とその特徵, 橋梁と基礎, 94-3, pp.26-31，1994年3月.

(1995.1.20 受付)

\title{
A SEISMIC EVALUATION METHOD FOR REINFORCED CONCRETE BRIDGE PIERS WITH INADEQUATE ANCHORING LENGTH AT TERMINATION OF MAIN REINFORCEMENTS
}

\section{Kazuhiko KAWASHIMA, Jun-ichi HOSHIKUMA and Shigeki UNJOH}

\begin{abstract}
To evaluate seismic vulnerability of existing reinforced concrete bridge piers with inadequate anchoring length at termination of main reinforcements at mid-height, a series of cyclic loading tests were conducted. A seismic evaluation method by means of the failure mode factor $\mathrm{S}$ and the safety factor $F_{y} T$ was proposed based on the test results. To show the effectiveness of the seismic evaluation method, seismic vulnerability was analyzed for 14 piers damaged/undamaged during the Kushiro-oki earthquake of January 1993 and the Hokkaido-nansei-oki earthquake of July 1993. The analytical results show that the piers vulnerable to cause shear failure at the termination zone can be satisfactorily predicted by the seismic evaluation method proposed in this paper.
\end{abstract}

